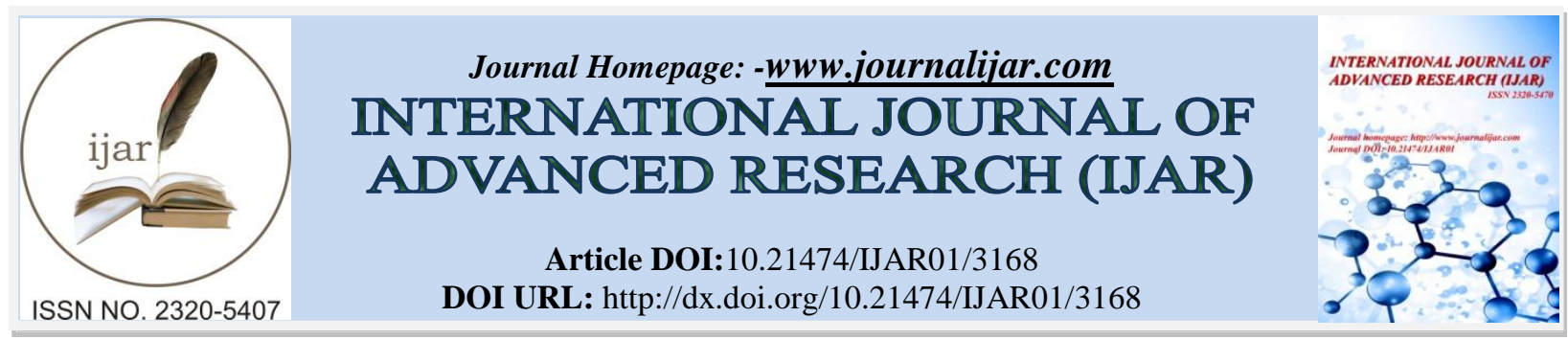

RESEARCH ARTICLE

\title{
THE INVESTIGATION OF GRATIFICATION CRIME: AN ANALYSIS OF CRIMINAL LAW ENFORCEMENT IN INDONESIA.
}

\author{
Andi Muliyono ${ }^{1 *}$, SyamsulBachri ${ }^{2}$, Andi Sofyan ${ }^{2}$ and M. Said Karim². \\ 1. Manokwari Law School, Jl. KaryaAbri, Sanggeng, Manokwari, West Papua 98312, Indonesia. \\ 2. Graduate School, Hasanuddin University, Jl. Perintis Kemerdekaan KM.10, Makassar, South Sulawesi 90245, \\ Indonesia.
}

\section{Manuscript Info \\ (n......................... \\ Manuscript History}

Received: 15 December 2016

Final Accepted: 08 January 2017

Published: February 2017

Key words:-

Criminal Law, Criminal Justice System, Investigation, Synchronization

\begin{abstract}
This study examines the essence of investigation authority against gratification crimes. This study aimed to provide an overview of the synchronization and harmonization of investigation systems on gratification in criminal law enforcement in Indonesia. The study was carried out by using a normative research, primary legal, secondary and tertiary materials, with deductive-reasoning method. The results of study showed that the investigative authority against corruption in general and gratification in particular are given the responsibility to the police, judiciary and the Corruption Eradication Commission of Indonesia. The third of law enforcement agencies, in addition to the authority to conduct investigations, was also given authority as coordinator, supervisor and controller of gratification crime investigation under the Act that became the legal basis respectively. Act that become investigation basis for both judiciary and the Corruption Eradication Commission rule out the concept of coordination and supervision as defined in the provisions of the Criminal Procedure General in this regard is the Code of Criminal Procedure. Therefore, the concept of inter-agency coordination, in addition not have a strong legal foundation is also a potential conflict of interest and the main obstacle in law enforcement against gratification crime.
\end{abstract}

Copy Right, IJAR, 2017,. All rights reserved.

\section{Introduction:-}

The strategic role between agencies, especially the eradication of corruption in law enforcement is a unity of integrated legal system. The term of integration in the context of enforcement agencies' role in the criminal justice sphere, known as the integrated criminal justice system.

According to Larry J. Siegel and Joseph J. Senna, looking at the criminal justice system as follows: "Criminal justice may be viewed or defined as the system of law enforcement, adjudication, and correction that is directly involved in the apprehension, prosecution, and control of those charged with criminal offenses"1

\footnotetext{
${ }^{1}$ Larry J. Siegel and Joseph J. Senna, Essentials of Criminal Justice. (USA : Thomson Learning, 2007), page 28
} 
B.N.Arief, ${ }^{2}$ argued there are 4 (four) components of the criminal justice in power subsystems, namely: 1 . the power of investigations; 2 . the power of prosecution; 3 . the power to prosecute and convict; and 4 . the power of criminal execution. While, I.S.Adji, ${ }^{3}$ divides 4 (four) institutions that carry out the criminal justice system, namely: 1 . Police institute; 2. Prosecution institute; 3. Judiciary institute; and 4. Penitentiary. The authority of law enforcement agencies above is the authority of attribution which comes from the 1945 Constitution and Act. $^{4}$

Indeed, from the aspect of formal crime legal, ${ }^{5}$ the handling of special crimes, the police have the authority as the investigation and investigator bodies ${ }^{6}$ although it has itself regulation, not many differences in the handling of corruption special criminal of the police and the prosecution institute, including ad hoc institution such as Corruption Eradication Commission.

One particularity of the Act of the Eradication of Corruption concerns the material criminal law of gift and receipt of gratification. Regulatory review that gratification can be considered bribery act, if it associated with his/her position and contrary to his/her obligations and duties. In other words, gratification has a negative impact and can be abused, especially in service delivery for the public sector in the government, so entered into the legislation concerning corruption crime.

Correspondingly, when observe the implementation of duties for the third of law enforcement agencies above, the handling of corruption associated with the gratification, can be ascertained that the Corruption Eradication Commission is a body of investigation, investigator and prosecutor are very prominent and optimized to eradicate gratification in law enforcement for corruption cases. The granting of authority to the police officers, prosecutors, and the Corruption Eradication Commission to investigate corruption cases did not cause corruption diminish but that seems on the surface is the pull of authority between the institutions that impact on the delay of the law enforcement process. For example, in District Court of Ciamis ever happened a corruptor acquitted because the judge considers that the competent institution to investigate is prosecutor not police consequently corruptor were released.

Overlapping between subsystems within the criminal justice system about who is authorized to conduct investigations on corruption cases. ${ }^{7}$ In grammatical, the meaning of a sentence based on the criminal law referring to Act No. 8 of 1981 on the Criminal Code, because in addition to the Criminal Code there is no other criminal procedure law applicable in Indonesia.

In Indonesian's criminal justice system, the position of the Prosecutor has a central role. It is not independent of the prosecutor authority in terms of determines whether a case can be filed to the trial or not. The authority to determine whether a case can be continued or not based on valid evidence is Dominus Litis owned by Indonesian prosecutor. ${ }^{8}$

Under the provisions of Article 35 of the Act No. 16 of 2004 on the attorney that: "The Attorney General has the duty and authority to: a) establish and control of law enforcement and justice policies within the scope of duties and authority of the prosecutor; b) streamline the process of law enforcement provided by law. "The provision authorizes the prosecutor to control the investigation, including the investigation of corruption crime in which there is a criminal act of gratification.

\footnotetext{
${ }^{2}$ BardaNawawiArief, KapitaSelektaHukumPidanatentangSistemPeradilanPidanaTerpadu(Integrated Criminal Justice System), Semarang: Diponegoro UniversityPress 2011), page.15

${ }^{3}$ Indriyanto Seno Adji, ArahSistemPeradilanPidana, (Jakarta: Prof. Oemar Seno Adji, S.H \& Co. Law firm, 2001), page. 49

${ }^{4}$ The authority of police institution as stipulated in Article 30 paragraph (4) of the 1945 Constitution that: "National Police of the Republic of Indonesia as the state's instrument to maintain the public security and orderliness shall be assigned to protect, serve the public, and reinforce the law".

${ }^{5}$ Formal criminal law contains regulation that regulates how the criminal law that is abstract must be applied in concrete. Often, the person mention the type of this law as criminal law in P.A.F. Lamintang, Dasar-DasarHukumPidana Indonesia, (Bandung: SinarBaru, 1984), page.10

${ }^{6}$ Article 5 and 7 Act No. 8 of 1981.

${ }^{7}$ Roy, Subir Kumar. (2016). "Consumer Justice: A Symbol of Economic Prosperity and Social Progressiveness." Hasanuddin Law Review,2(2): 170-181. DOI: http://dx.doi.org/10.20956/halrev.v1n2.302

${ }^{8}$ Marwan Efendi, Kejaksaan R.I, PosisidanfungsinyadalamPerspektifHukum, (Jakarta : Gramedia, 2005), page. 105
} 
Furthermore, the investigator of Indonesian National Police are given authorities as coordinator and investigation supervisory, as defined in Article 7 paragraph (2) of Act No. 8 of 1981 on Procedure of Criminal.

The third of investigators - the police, judiciary and the Corruption Eradication Commission are given the authority to investigate criminal such as gratification, each is given authority as coordinators, supervisors and controllers. Thus, the system of coordination between institutions that built does not have a strong legal foundation, and can give rise to multiple interpretations which resulted disharmonious and not synergetic in the coordination of interinstitutions.

In this context, corruption as a violation of social and local economy rights as an extraordinary crime, the eradication measures can no longer be done "as usual" but "demanded by extraordinary enforcement. ${ }^{9}$

\section{Identification of the Issue:-}

The issue to be discussed in this article is about "how the synchronization of gratification crime investigation in law enforcement in Indonesia."

\section{Method of the Research:-}

Type of this study was normative. The study examines the concept of investigation authority for gratification crime in criminal law enforcement in Indonesia, so it can be constructed the concept of synchronization synergistically in the investigation system. The data used were secondary data that consists of primary law materials in the form of legislation, tertiary legal materials such as reference books, expert opinion or the results of previous research, and tertiary legal materials such as dictionaries, scientific laws dictionary and black law dictionary.

The method of analysis in this article begins by abstracting primary, secondary and tertiary legal materials, in order to know the essence of investigative authority for gratification crime in criminal law enforcement in Indonesia, to analyze the weaknesses of legality for each investigative institutions, conduct systematically and lastly by using deductive-syllogism reasoning.

\section{Analysis and Discussions:-}

\section{The Scope of Gratification in Criminal Justice System:-}

Recently, the eradication of corruption is no longer just a national issue for a country only, but has become an international problem involving many countries. Corruption has become a transnational crime whose eradication requires cooperation from various countries. The condition was confirmed in the United Convention Against Corruption (UNCAC), which states:

"Convinced also that the globalization of the world's economic has led to a situation where corruption is no longer a local matter but a transnational phenomenon that affects all societies and economies, making international cooperation to prevent and control it essential."

Many poor and developing countries in Asia and Africa as a victim states are very experienced negative impact as a result of corrupt practices. Even then corruption is regarded as one of the causes of sluggish economic growth and leads to a low level of social welfare.

In a study conducted by the IMF donors in 1996, states that corruption can have consequences significantly decelerate economic growth. Based on the formulation of corruption substances in the United Nations Convention Against Corruption as described above, it can be understood that the arrangement of corruption law material are not formulated specifically about gratification. Observing the formula above, it can be concluded that gratification were formulated in Act No. 31 of 1999 on Corruption Eradication in Indonesia is the interpretation of elaboration of bribery substance.

Bribery crime in the formulation of the United Nations Convention Against Corruption is always followed by the key elements, namely: a) Act or refrain from acting in the execution of his official duties; b) Trading in influence; c) misappropriation of influence; d) Abuse of functions; e) Trading in influence; f) Illicit enrichment. Elements of such actions are bribery and gratification elements in Indonesia Corruption Act. Therefore, the limitation of difference between bribery and gratification becomes blurred or unclear.

${ }^{9}$ ErmansyahDjaja, MemberantasKorupsiBersama KPK, KomisiPemberantasanKorupsi, (Jakarta :SinarGrafika, 2009 ), page. 28. 
United Nations Convention against Corruption is also advocate and emphasize to each member state, in order to adopt the legislative action and other measures necessary to establish into the substance in the Acts or national laws regarding corruption meets international standards. Therefore, the corruption eradication acts should be amended in accordance with the substance of the United Nations Convention Against Corruption, in order that the Acts meets international standards and facilitate the Indonesian state in the process of law enforcement against corruption within the scope of corruption outside the jurisdiction (international).

Gratification elements can be obtained from the elucidation of Article 12B of Act No. 20 of 2001, the gift in a broad sense, including money, goods, rebate (discount), commissions, interest-free loans, travel tickets, lodging, tours, free medical treatment, and other facilities. Such gratification whether received at home and abroad and carried out by using electronic means or not. ${ }^{10}$

The definition shows that gratification is actually meaningful gift that is neutral. A gift becomes a gratification as bribe if related to the position and contrary to the obligation or duty of the recipient. ${ }^{11}$

Basically, gratification is a new type of criminal. According to Eddy Omar Sharif, a professor of criminal law in faculty of law, GadjahMada University, argued that "the differences of gratification and bribes lies on whether or not a meeting of mind at the time of receipt. On the crime of bribery, there is a meeting of mind between the giver and recipient of bribes, while in gratification crime there is no meeting of mind between the giver and the recipient. Meeting of mind is another name of consensus or things that are transactional."

According to AdamiChazawi, mentioned differences gratification and bribery, that "the provisions of gratification has been no malicious intent (mens rea) of the recipient at the time the money or goods received. Malicious intent exists when such gratification is not reported within 30 working days, so that after passing the time regarded bribe until proven otherwise. Whereas the provisions on bribery, the recipient has malicious intent when money or goods are received."

Settings and the mention of gratification specifically known since the enactment of Act No. 20 of 2001 on Amendments to the Act No. 31 of 1999 on the Corruption Act. The Act provides for the obligation of public servants or state officials to report to the Corruption Eradication Commission any gratification associated with the position and contrary to the duties or obligations of the recipient. If the gratification that considered as bribery is not reported to the Corruption Eradication Commission, then there is a risk of violation of the law both in the realm of administrative or criminal.

\section{The Authority of Investigation in Gratification:-}

In addition to police investigators, prosecutors and the Corruption Eradication Commission, there are also some institution of civil servant investigators are authorized to handle the interrogation of criminal related to the field of duty or legislation on which the respective law. There are some investigative institutions which according to existing legislation is given the authority to conduct investigations.

In practice, it is possible to avoid overlapping of authority, especially in complex cases associated with some legislation. In the absence of a particular institution that integrates the distribution of authority in the investigation process, the mechanism of coordination and supervision in the investigation process was very difficult in practice. Each investigator often operate on their own and thus potentially creating conflicts among investigators itself due to the overlap of authority. ${ }^{12}$

\section{Police Investigator:-}

Pursuant to Article 14 letter g of Act No. 2 of 2002 on the Indonesian National Police, that:

\footnotetext{
${ }^{10}$ KomisiPemberantasanKorupsi, PedomanPengendalianGratifikasi, (Jakarta: KPK, 2015), page. 9.

${ }^{11}$ Ibid, page. 9.

${ }^{12}$ Sukardi, IllegalLoggingdalam PerspektifPolitikHukumPidana: KasusPapua, (Yogyakarta: UniversitasAtmaJayaPress, 2005), page. 128 .
} 
"The Indonesian National Police assigned to conduct investigations and inquiries to all parties in accordance with the criminal law procedure and other legislation".

The process of corruption handling by police investigators using procedure as a case of common criminal, which is based on the Criminal Procedure Code. ${ }^{13}$ Any investigation conducted by the Police always followed up with a Notice of Commencement of Investigation to the public prosecutor, and then public prosecutor conduct preprosecution, to examine the completeness of case files, both formal and its material and to give instructions. ${ }^{14}$

Under the terms of Act No. 8 of 1981 on Criminal Law Procedure which is some formal provisions applicable in general, the Indonesian National Police is the institution that given "the responsibility of management" in the investigation of crime. Therefore, for synergy and harmonization of criminal investigation system, then all institutions of the investigator should be in a system of coordination and under the supervision of the Indonesian National Police Investigator.

\section{Attorney Investigator:-}

The provisions of Article 1 (1) of Act No. 16 of 2004 regarding the Attorney of the Republic of Indonesia determined that prosecutors were functional which is authorized by this Act to act as a public prosecutor and the executor of court decisions that have acquired the force of law and other authority under Act. The Attorney of the Republic of Indonesia as a state institution of government that implements state power in the prosecution must be free from the influence of government power and other.

According to EviHartanti, ${ }^{15}$ attorney as a public prosecutor in a criminal case must know clearly all work to be done investigator from the beginning until last things to be done by law. Attorney will account for all of treatment of the accused began to suspect investigated, then examined his/her case, then arrested, and finally whether the prosecution conducted by the attorney is valid and correct or not according to the law, so it's really a sense of justice are met.

The enactment of Act No. 8 of 1981 on Criminal Law Procedure abdicates the authority of investigation of attorney agencies and fully handed over to the Police. With the enactment of the Criminal Code, the authority of investigation is only charged to the Police as a single investigator. However, with the provisions of Article 284 paragraph (2) still allow other investigator beside police that is attorney to conduct an investigation for certain crime perpetrators, including corruption. ${ }^{16}$

The authority of attorney as investigation controller defined in the provision of article 35 letter a Act No. 16 of 2004 on the attorney is unclear because few considerations: The Attorney General has the duty and authority to set and control the policy of law enforcement and justice within the scope of duties and authority of the attorney.

\section{The Corruption Eradication Commission Investigator:-}

The Corruption Eradication Commission ${ }^{17}$ is the state institute in conduct its duties and authorities are independent and must be free from any influence, it is similar to other institutions have the authority to carry out duties and its objectives. In outline, the authority of the Corruption Eradication Commission in Act No. 30 of 2002 on the Corruption Eradication Commission can concluded with the details; the authority as duties of the Corruption Eradication Commission, the rights to exercise authority, the authority relating to technical implementation of duties and others.

The duties and authority of the Corruption Eradication Commission as gratification investigator in Article 6 paragraph (1) letter c of Act No. 30 of 2002 on the Corruption Eradication Commission as follows: conduct an inquiry, investigation, and prosecution of corruption. The authority of investigation by the Corruption Eradication

\footnotetext{
${ }^{13}$ Said Karim Mispansyah, Harustiati A. Moein Irwansyah. "Justice in Granting Remission for Corruption Prisoners (A Review of Indonesian Criminal Justice System)." International Journal of Scientific \& Technology Research, 4(11): 208-213

${ }^{14}$ Andi Hamzah, PengantarHukum Acara Pidana, (Jakarta: Ghalia Indonesia, 1983), pages. 75 - 77

${ }^{15}$ EviHartanti, TindakPidanaKorupsi:EdisiKedua, (Jakarta: SinarGrafika, 2007), page. 32

${ }^{16}$ Faisal Salam, Hukum Acara PidanaDalamTeoridanPraktik, (Bandung: MandarMaju, 2001), page. 138.

${ }^{17}$ The KomisiPemberantasanKorupsi (KPK) is the Indonesian Corruption Eradication Commission, which was formed after special consideration on the extraordinary nature of corruption in Indonesia, which has become systemic and widespread, and has violated the human rights of the Indonesian people. The KPK was formed under Act No. 30 of 2002 on the Corruption Eradication Commission.
} 
Commission is special investigative procedures were given authority to the Corruption Eradication Commission. However, the special authority override the general procedure set forth in the provisions of the criminal law procedure, that is in Act No. 8 of 1981 on Criminal Law Procedure. It is as defined in Article 38 paragraph (2) of Act No. 30 of 2002 on the Corruption Eradication Commission, that:

1. All authorities related to inquiry, investigation, and prosecution as stipulated in Act No. 8 of 1981 on Criminal Law Procedure applied also to investigators, and public prosecutors at the Corruption Eradication Commission.

2. The provisions referred to in Article 7 paragraph (2) of Act No. 8 of 1981 on Criminal Law Procedure does not apply to the corruption investigator as defined in this Act.

Related to the existence of investigation by the Corruption Eradication Commission, it interesting to observe considerations of the judge in the decision of pretrial in the District Court of South Jakarta No. 36/Pid.Prap/ 2015/PN.Jak/Sel. Based on consideration of the judge mentioned above, it can be understood that the judge in interpreting the provisions of the Act do not just use grammatical interpretation alone in interpreted the word of case of Act as the everyday sense, but also judges using teleological interpretation as interpretation of the purpose of law by law maker.

In this case, the judge to try to understand the will or intent contained in the formulation of article purpose by the maker. In addition, the judge also uses a systematic interpretation by looking the provisions of Corruption Act as one element in the criminal law system; therefore, the Act must not conflict with other both horizontally and vertically.

The consideration of judge about the existence of Corruption Eradication Commission investigators are sourced from police officers who had been dismissed as police investigators, reinforce the belief that the legality of the Corruption Eradication Commission investigators can affect the legality of legal products in the form of administrative and investigation actions and investigations conducted by the Corruption Eradication Commission investigators.

\section{The Concept of Coordination Synergic Between Investigator:-}

Coordination is the process of integrating the objectives and activities of distinct units (functional departments) within an organization to achieve objectives efficiently and effectively. ${ }^{18}$ According to E.F.L. Brech in his book, "The Principle and Practice of Management", the coordination is to balance and move the team to give the location of activities appropriate to each and maintain the activities carried out with proper alignment between the members themselves. ${ }^{19}$

Based on the definition above, it may be mentioned that coordination has requirements that:

a. Sense of Cooperation, the feeling of working with each other, looked per section.

b. Rivalry, in large organizations, often held a competition between departments, in order to compete with each other

c. Team Spirit, one another per section should be mutual respect.

d. Esprit de Corps, a part of mutual respect will be more excited.

Nevertheless, in practice the coordination between law enforcer, including the level of coordination of the criminal justice system is still showing lack of a common vision in the direction of law enforcement. ${ }^{20}$ This is possible due to a variety of interests and differences in the interpretation and perception of the existence of gratification itself, whether arising scientifically and influenced by a variety of interests and other aspects such as politics, economy and social culture.

Gratification crime is a case that multi-dimensional involves various agencies and stakeholders that exist. Therefore, the law-enforcement efforts also would involve various agencies and institutions involved. Coordination with agencies/related-government officials in relation to corruption in order to handle cases with indications of

\footnotetext{
${ }^{18}$ T. Hani Handoko, Manajemen, (Yogyakarta: BPFE, EdisiKedua, 2003), page. 195

${ }^{19}$ SoewarnoHandayaningrat, PengantarStudiAdministrasidan Management, (Jakarta: GunungAgung, 2002) page. 54

${ }^{20}$ Arie, M. (2016). An Approach of Legisprudence Theory to Assess the Quality of Local Regulation. Hasanuddin Law Review, 2(3), 371-384. doi:http://dx.doi.org/10.20956/halrev.v2i3.699
} 
gratification, in fact is very difficult. Concerned agencies are often less transparent/support in the disclosure of gratification occur.

This is consistent with the theory put by SoerjonoSoekanto, ${ }^{21}$ that the success of law enforcement is not solely concerning the enforcement of applicable law, but depends also on several factors: ${ }^{22}$

First, the law, the legislation should be made to follow the principles that apply, such as the legislation is not retroactive, that are specifically override the general laws; it made by higher authorities have a higher position as well; it that apply later to overturn legislation in force earlier, it is not inviolable. Similarly, the legislation should be eligible in philosophical/ ideological, jurisdiction terms and socio-logical, it means the legislation are made must not conflict with the ideology of the state and it must be made in accordance with the provisions governing the authority of legislators as set out in the state constitution, and it must be in accordance with the needs and conditions of the society in which it is enforced.

Second, the law enforcer, the parties directly involved in the field of law enforcement that includes law enforcement and peace maintenance. Law enforcement must conduct their duties properly in accordance with their respective roles that have been regulated in legislation. In conduct these duties by emphasizing fairness and professionalism, so that it becomes a model for community and trusted by all parties, including all members of society.

Third, the means or facilities to support law enforcement. The facilities include a means or manpower that have been educated and skilled, good organization, adequate equipment, adequate financing, and so on. Availability of adequate facilities is a necessity for the success of law enforcement.

Fourth, the community, the community environment in which they may apply or applied. It means, that community should know and understand the laws that apply, as well as complying with the law would apply to full awareness and necessity of the law to peoples' lives.

Fifth, the culture, as a result of the work, creativity and taste which is based on human initiative in social life. In this case the culture includes the values underlying the applicable law, the values of which are abstract conceptions of what constitutes good so embraced, and what is considered bad so avoided.

\section{Conclusion:-}

In general, the authority of investigation against corruption and gratification in particular are given to the police, judiciary and the Corruption Eradication Commission. The third of law enforcement agencies, in addition has authorities to conduct investigations, was also given authority as coordinator, supervisor and controller of gratification investigation system. Act as basis of investigation against judiciary and the Corruption Eradication Commission rule out the concept of coordination and supervision as defined in the Indonesian Criminal Procedure Law. Therefore, the concept of coordination between investigative agencies, in addition to not have a strong legal foundation, is also a potential conflict of interest and the main constraint in law enforcement against gratification criminal acts.

Needed a revision of the related-Act to realize the coordination systems are synergic and harmony between law enforcement agencies. The judiciary as the only agency of the prosecution, ideally just given responsibility as the prosecution and not charged for investigation authorities, to be more professional in the field of prosecution. Meanwhile, the Corruption Eradication Commission as investigator should ideally be recruited as a civil servant investigators and coordination system and investigative supervision under the Police investigator.

\footnotetext{
${ }^{21}$ SoerjonoSoekanto, Faktor-faktor Yang MempengaruhiPenegakanHukum, (Jakarta: Rajawali Press, 2008), pages. 5-8.

${ }^{22}$ HibnuNugroho,

EfektivitasFungsiKoordinasidanSupervisidalamPenyidikanTindakPidanaKorupsiolehKomisiPemberantasanKorupsi, (Paper).Purwokerto: UniversitasJenderalSoedirman, pages. 398-399
} 


\section{References:-}

1. Arie, M. (2016). An Approach of Legisprudence Theory to Assess the Quality of Local Regulation. Hasanuddin Law Review, 2(3), 371-384. doi:http://dx.doi.org/10.20956/halrev.v2i3.699

2. Andi Hamzah. (1983).PengantarHukum Acara Pidana. Jakarta: Ghalia Indonesia.

3. BardaNawawiArief. (2011).KapitaSelektaHukumPidanatentangSistemPeradilanPidanaTerpadu(Integrated Criminal Justice System). Semarang: Diponegoro University Press.

4. ErmansyahDjaja. (2009). MemberantasKorupsiBersama KPK.KomisiPemberantasanKorupsi, Jakarta:SinarGrafika.

5. EviHartanti. (2007). TindakPidanaKorupsi:2nd Edition. Jakarta: SinarGrafika.

6. Faisal Salam. (2001). Hukum Acara PidanaDalamTeoridanPraktik, Bandung: MandarMaju.

7. HibnuNugroho, 2008, EfektivitasFungsiKoordinasidanSupervisidalamPenyidikanTindakPidanaKorupsiolehKomisiPemberantasanKor upsi, (Paper).Purwokerto: UniversitasJenderalSoedirman.

8. Indriyanto Seno Adji. (2001).ArahSistemPeradilanPidana. Jakarta: Prof. Oemar Seno Adji, S.H \& Co. Law firm.

9. KomisiPemberantasanKorupsi. (2015).PedomanPengendalianGratifikasi, Jakarta: KPK.

10. Larry J. Siegel and Joseph J. Senna. (2007).Essentials of Criminal Justice. USA: Thomson Learning.

11. Marwan Efendi. (2005), Kejaksaan R.I, PosisidanFungsinyadalamPerspektifHukum, Jakarta: Gramedia.

12. Mispansyah, Said Karim,Harustiati A. Moein Irwansyah. "Justice in Granting Remission for Corruption Prisoners (A Review of Indonesian Criminal Justice System)." International Journal of Scientific \& Technology Research, 4(11): 208-213

13. P.A.F. Lamintang. (1984).Dasar-dasarHukumPidana Indonesia, First edition. Bandung: SinarBaru.

14. Roy, Subir Kumar. (2016). "Consumer Justice: A Symbol of Economic Prosperity and Social Progressiveness." Hasanuddin Law Review,2(2): 170-181. DOI: http://dx.doi.org/10.20956/halrev.v1n2.302

15. SoerjonoSoekanto. (2008). Faktor-faktor Yang MempengaruhiPenegakanHukum, Jakarta: Rajawali Press.

16. SoewarnoHandayaningrat. (2002). PengantarStudiAdministrasidan Management, Jakarta: GunungAgung.

17. Sukardi. (2005).IllegalLoggingdalam PerspektifPolitikHukumPidana: KasusPapua, Yogyakarta: UniversitasAtmaJayaPress.

18. T. Hani Handoko. (2003). Manajemen. 2nd Edition. Yogyakarta: BPFE.

19. United Nations Convention Againts Corruption, 2003. 